\title{
EDITORIAL
}

Open Access

\section{IMPACT OF COVID-19 PANDEMIC ON MEDICAL EDUCATION, AN EXPERIENCE AT UNIVERSITY MEDICAL AND DENTAL COLLEGE}

\author{
Sundus Tariqa, Saba Tariq ${ }^{b}$, Akram Malikc \\ ${ }^{a}$ Associate Professor, Physiology, University Medical \& Dental College, The University of Faisalabad. \\ ${ }^{b}$ Associate Professor, Pharmacology and Therapeutics, University Medical \& Dental College, The \\ University of Faisalabad. \\ 'Editor JUMDC, University Medical \& Dental College, The University of Faisalabad.
}

\section{How to cite this:}

https://doi.org/10.37723/jumdc.v12i3.663

Tariq S, Tariq S, Malik A. Impact of COVID-19 pandemic on Medical Education, An experience at University Medical and Dental College. Journal of University Medical \& Dental College. 2021;12(3):vvi. https://doi.org/10.37723/jumdc.v12i3.663

This is an Open Access article distributed under the terms of the Creative Commons Attribution License (http://creativecommons.org/licenses/by/4.0), which permits unrestricted use, distribution, and reproduction in any medium provided the original work is properly cited.

Life was running smoothly with little vicissitudes, until the world encountered COVID-19 pandemic. This unexpected pandemic not only interrupted the routine life of individuals but also drastically altered the education system worldwide, affecting more than 1.6 billion learners in nearly 190 countries ${ }^{[1]}$. Who have imagined that every day, we would be welcomed by the university with a sprinkle of water? Masks, hand sanitizers and gloves replacing lipsticks and foundations in our bags, books replaced by gadgets. Changing instructions for students from "do come to the college", to "do not come to the college" and "do not use mobile phones" to switching them to screens for most part of the day.

This radical change was inevitable and only solution was to cope with it timely and that is what most medical colleges have achieved by stimulating innovation and mindfulness among faculty, students and administration.

The first case of coronavirus in Pakistan was reported from Karachi in the end of February 2020 and lockdown was imposed on 24 March 2020 with the closure of all educational institutes in Punjab [2]. In this short span, the university management and faculty was preparing to meet the demands of future educational needs. Faculty was brought on a single platform to make this transition smooth. Their enthusiasm was overwhelming and the desire to participate was outstanding despite the age bracket. Infact, the senior faculty members volunteered to initiate all the new activities, which they would have never attempted otherwise.

The initial transition phase was most challenging as the faculty and especially students were not sure how to carry things forward. To carry on the educational cycle, the dynamics of medical curricula was rearranged, the faculty members generated google classrooms and started online teaching. Within two weeks' time all the classes were shifted to official accounts to keep official record of all the activities. In addition, the concept of telemedicine and telehealth was introduced for the very first time as this was becoming integral for student and doctor patient interaction ${ }^{[3]}$.

It was not possible for all the students to join the online classes regularly due to socioeconomic factors, older technology, unreliable internet, small children and multiple family members at home and insecure living conditions, that were hindering their learning. To sort out all the issues, small groups were created and assigned to particular facilitators whose responsibility were to chalk down possible challenges beforehand and come forward with their solutions, to facilitate student learning in a better way. It was also ensured that lectures and other activities were recorded and provided to students on multiple platforms like whats app, you tube etc., other than the official classrooms so JUMDC Vol. 12, Issue 3, July-September, 2021 
that they can have access to the learning material all the time.

Small groups lead by student representatives and supervised by a faculty member were also created on whats app to deal with day-to-day issues of the students. In fact, the staff was available 24/7 to deal with students in this time of crises. In addition, student grievance information technology (IT) cell and student grievance human resource (HR) cell were also created and links were generated on which students can contact the particular cells to get their issues resolved. The peers as well as faculty motivated students time to time and motivational sessions other than course were also carried out to prevent depression and anxiety among students.

All the lectures, tutorials, alternative to practical's, small group discussions and assessments were carried according to the scheduled timetables.

Assessments were challenging and during the assessment process, the focus was kept on learning. Assessments were designed by balancing structure with flexibility, using alternative methods and tools by which students and faculty were well conversant, and carried in environment in which academic integrity was not compromised with clear instructions and quality feedback followed by proper evaluation of the whole assessment process. On-campus and online workshops, webinars, seminars and training sessions were arranged for faculty and students as we believe in sharing the experiences and getting benefit from other experiences to improve the learning process. Research activities were arranged and quality research was conducted to bridge the knowledge, awareness and attitudes (KAP) gap ${ }^{[4]}$.

In addition to all the efforts that everyone put in, a dire need of universities' own strong learning management system was felt, that should include options to build various assessment methods for students, spontaneous scoring, item analysis, individual timer, randomization and e-proctoring tools. In addition, it can be customized according to needs of individual departments.

Though it was a challenging time for all of us and we tried to deal with it in the best possible way, using all the available resources, but the fact is online learning process can never replace face-to-face live learning experiences. Artificial intelligence can never replace human intelligence as is mentioned in Holy Quran, We created humans 'ahsane taqvim' (Quran; 95:4). It is stated in Surah Bani Isra'il thus: "We have honoured the children of Adam, provided them with transport on land and sea, given them for sustenance things good and pure, and made them superior to a great number of Our creations." (Quran; 17: 70).

These unexpected challenges in life should be taken positively as these moments bring out a fighting spirit, motivation and a revived appreciation for all the blessings we have in life. It also reminds us that anything used in a positive way can be of great benefit for humanity as a distractor like android phone has become a powerful tool for learning.

Cherish your blessings before they are taken away and always be thankful for whatever you have.

\section{REFERENCES:}

1. De Giusti A. Policy Brief: Education during COVID-19 and beyond. Revista Iberoamericana de TecnologíaEnEducación y Educación En Tecnología. 2020;12(26):e12-.Doi:10.24215/18509959.26. e12

2. Tariq S, Tariq S, Baig M, Saeed M. Knowledge, Awareness, and Practices Regarding the Novel Coronavirus Among a Sample of a Pakistani Population: A Cross-Sectional Study. Disaster Medicine and Public Health Preparedness. 2020:1-6.Doi:10.1017/dmp.2020.408

3. Franklin G, Martin C, Ruszaj M, Matin M, Kataria A, Hu J, Brickman A, Elkin PL. How the COVID-19 Pandemic Impacted Medical Education during the Last Year of Medical School: A Class Survey. Life. 2021;11(4):294.Doi:10.3390/life11040294

4. Tariq S, Tariq S, Baig M, Alam SS. Adequacy of preventive measures, awareness, and attitude regarding the COVID-19 pandemic among university pharmacy students. Pharmacy Education. 2020:283-289.Doi: 10.46542/pe.2020.202.283289. 